Viso - Cadernos de estética aplicada Revista eletrônica de estética

ISSN 1981-4062

$N^{0} 6$, jan-jun/2009

http://www.revistaviso.com.br/

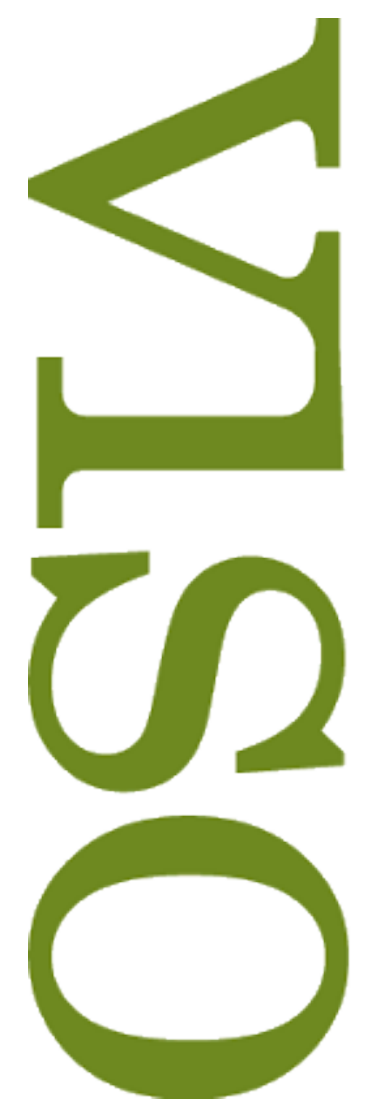

\title{
A poesia inglesa e a retórica aristotélica: a atualidade dos discursos poéticos e preceptivos no século $X V I$
}

Lavinia Silvares Fiorussi 


\section{RESUMO}

A poesia inglesa e a retórica aristotélica:

a atualidade dos discursos poéticos e preceptivos no século XVI

Este artigo trata da produção discursiva sobre o regramento da poesia divulgada na Inglaterra, entre a segunda metade do século XVI e a primeira metade do século XVII, pressupondo a vigência da retórica aristotélica como doutrina organizadora do pensamento e das artes. Assumindo uma abordagem teórica não-reflexológica, este artigo considera que os tratados de retórica e de poética em questão têm seu próprio valor como artefatos da linguagem, constituindo, ao mesmo tempo, peças divulgadoras dos preceitos e das qualidades impostas ao fazer poético e, também, produtos do mesmo meio histórico e social em que se realiza a poesia.

Palavras-chave:

retórica - poética - poesia seiscentista inglesa - preceptivas

\section{ABSTRACT}

English Poetry and Aristotelian Rhetoric:

Preceptive and Poetical Discourses in the 16th Century

This essay discusses the discursive production, in England, concerning poetry between the second half of the 16th century and the first half of the 17th century, assuming that the Aristotelian Rhetoric was an active doctrine in this period. Adopting a non-reflexive theoretical approach, this essay considers that the treatises on Rhetoric and Poetry have a value of their own as language artefacts, being, at the same time, texts that expose the precepts and the qualities imposed to the poetical production of the time, and, also, products of the same historical and social milieu where poetry is being written.

\section{Keywords:}

rhetoric - poetics - Elizabethan poetry - treatises 
FIORUSSI, L. S. "A poesia inglesa e a retórica aristotélica: a atualidade dos discursos poéticos e preceptivos no século XVI". In: Viso: Cadernos de estética aplicada, v. III, n. 6 (jan-jun/2009), pp. 23-49.

DOI: $10.22409 / 1981-4062 / v 6 i / 69$

Aprovado: 24.05.2009. Publicado: 14.07.2009.

(C) 2009 Lavinia Silvares Fiorussi. Esse documento é distribuído nos termos da licença Creative Commons Atribuição-NãoComercial 4.0 Internacional (CC-BY-NC), que permite, exceto para fins comerciais, copiar e redistribuir o material em qualquer formato ou meio, bem como remixá-lo, transformá-lo ou criar a partir dele, desde que seja dado o devido crédito e indicada a licença sob a qual ele foi originalmente publicado.

Licença: http://creativecommons.org/licenses/by-nc/4.0/deed.pt_BR

Accepted: 24.05.2009. Published: 14.07.2009.

(C) 2009 Lavinia Silvares Fiorussi. This document is distributed under the terms of a Creative Commons Attribution-NonCommercial 4.0 International license (CC-BY-NC) which allows, except for commercial purposes, to copy and redistribute the material in any medium or format and to remix, transform, and build upon the material, provided the original work is properly cited and states its license.

License: http://creativecommons.org/licenses/by-nc/4.0/ 
I can love her, and her, and you and you,

I can love any, so she be not true. John Donne, The Indifferent

Com a queda do Antigo Regime na Europa, a Retórica, antiga doutrina mestra da produção e do julgamento das representações simbólicas, se desarticula e se desprende de disciplinas que, historicamente, Ihe eram ancilares ou complementares, como a Poética, a Ética e a Dialética. Considerada instrumento de persuasão próprio do regime absolutista, a prescrição retórica dos gêneros do discurso - vigente, por exemplo, na época de Shakespeare - será desacreditada em favor de uma nova conceitualização das artes e de seu domínio de criação e de função estético-social. A ruína da retórica aristotélica, expressa nos discursos literários e filosóficos dos séculos XVIII e XIX, é simultânea aos projetos iluministas e românticos da unificação das artes - antes concebidas separadamente enquanto techné específica - em uma esfera conjunta em cujo epicentro estará não a antiga mímesis aristotélica, mas a imaginação criadora de um ethos subjetivo. Nova e velha categoria, a imaginação será concebida em termos estético-filosóficos como a faculdade criativa que envolve a percepção sensorial diante de uma realidade empírica, a teorização do indivíduo subjetivizado e autocentrado e da historicidade da experiência humana.

Neste artigo, proponho-me tratar do âmbito retórico das práticas de representação em que se insere a chamada poesia "renascentista" inglesa (ou "elisabetana", "metafísica", "engenhosa" etc.) de William Shakespeare (1564-1616), Edmund Spenser (1552-1599), John Donne (1572-1631), entre outros. Supondo que a prática poética nos séculos XVI e XVII não constituía a expressão da imaginação, como no caso da arte romântica e pósromântica, pretendo expôr, aqui, uma sinopse da produção de tratados veiculadores de preceitos retórico-poéticos e de conceitualizações das artes que formavam e davam significado à representação mimética em língua inglesa. Assim, este artigo avalia que a instituição retórica na Inglaterra era fundamentada em preceitos e autoridades grecolatinas, conforme ocorria no caso de outras cortes cristãs dos séculos XVI e XVII; aborda preceitos da mímesis grega e da imitatio latina, bases da poesia de verossimilhança seiscentista; examina a valorização suprema da faculdade do wit (engenho) como aquela que permite ao poeta estabelecer analogias entre as coisas; e, por fim, exemplifica, através de comentários a uma elegia fúnebre de John Donne, o papel da retórica nas disputas letradas da época que buscavam autorizar modelos, solidificar o costume da poesia vernacular e estabelecer uma hierarquia própria entre os poetas de língua inglesa.

\section{Da historicização das práticas culturais}

O historiador austríaco E. H. Gombrich dizia que a história é um queijo suíço, cheio de buracos. Com isso, postulava que qualquer concepção que se proponha fazer de um passado acumula esses insuperáveis "vazios" de conhecimento, tremendas ausências 
de significação e de sentido. ${ }^{1}$ Michel de Certeau dizia que o passado, positivamente, é aquilo que não é mais; as ruínas dele se espalham no presente como roupas de náufragos jogadas na praia, náufragos cujos corpos há muito afundaram no mar da história. ${ }^{2}$ Como proceder, então, para examinar, hoje, as ruínas do passado - os índices de uma existência positiva do passado no passado? Gombrich propunha que o pesquisador (historiador das artes, das literaturas, dos costumes, das culturas etc.) mergulhasse no mar da história, lendo o máximo possível de textos (verbais e nãoverbais) produzidos na época que se estuda. Assim, argumentava ele, o pesquisador não apenas acumularia conhecimento (isso é uma obrigação, afinal de contas), mas acumularia "sensações" [feelings] sobre uma determinada época, a ponto de "intuir" melhor sobre o caminho mais adequado a seguir. Resumindo: lendo e relendo a produção textual, figurativa, simbólica, prescritiva de um determinado período talvez se possa adquirir um certo "know-how" sobre o que se pesquisa. E o resultado de tal exame profundo, de uma leitura densa dos documentos históricos, desse mergulho em águas passadas? O que poderia oferecer o pesquisador especialista? Um queijo suíço, certamente, cheio de buracos. O intervalo temporal que afasta presente e passado é também semântico (dizia R. Koselleck). É forçoso confessar o caráter necessariamente precário do estudo histórico, sabendo que talvez não seja o caso para todos os historiadores de fazer grandes generalizações, panoramas históricos - nesse sentido, Gombrich dizia que um dos grandes intérpretes da Renascença, J. Burckhardt, era mais um artista que um historiador, um pintor de grandes quadros históricos (como Watteau?).

Isso posto, alega-se que este artigo sobre a poesia "renascentista" (ou "eufuísta", "preciosista" - os rótulos são infinitos), ao propor ao leitor a discussão de tratados e preceptivas retórico-poéticas do século XVI, supõe que seja adequado colocar na roda da "análise estética" das obras de arte as conceitualizações correntes no período em que as obras foram produzidas. Tendo em vista que os conceitos têm uma história, supõe-se, por exemplo, que o termo "imagination", nos seguintes versos de Shakespeare, tenha uma significação e um sentido específicos:

The poet's eye, in a fine frenzy rolling,

Doth glance from heaven to earth, from earth to heaven,

And, as imagination bodies forth

The forms of things unknown, the poet's pen

Turns them to shapes, and gives to airy nothing

A local habitation and a name. ${ }^{3}$

E na tradução portuguesa:

Os olhos do poeta, em alvo postos,

Vão do céu à terra e da terra ao céu;

E como a imaginação arquitecta

O desconhecido, a pena do poeta

Dá-lhe formas, e confere ao que é nada

Uma existência própria e dá-Ihe um nome. ${ }^{4}$ 
Cruzando o enunciado poético de Shakespeare com um enunciado preceptivo do tratado The Defense of Poesy, de Sir Philip Sidney, publicado em 1595, é possível estabelecer um paralelo entre a concepção poética que posiciona a imaginação entre os pontos "the poet's eye" e "the poet's pen", adquirindo o sentido (aristotélico e pré-kantiano) de "ponte"/faculdade mental entre a percepção sensível do mundo e a figuração retóricopoética. Em seu tratado, Sidney formula o discurso de que o poeta expande os limites da natureza através de sua arte:

Apenas o poeta [...], levantado com o vigor de sua própria invenção, de fato faz nascer
outra natureza, ao fazer as coisas ou melhor do que a natureza as apresenta, ou,
inteiramente sob nova forma, formas tais que nunca houve na natureza, como os
Heróis, Semideuses, Cíclopes, Quimeras, Fúrias e outras assim: pelo que segue de
mãos dadas com a natureza, não enclausurado na estreita autoridade de seus dons,
mas livremente variando apenas dentro do zodíaco de seu próprio engenho. ${ }^{5}$

Passos como esse, de Sidney, evidenciam o pensamento sobre as artes e o fazer artístico que se encontra figurado na fantasia poética de, por exemplo, Shakespeare. Expandindo ou melhorando a natureza, o poeta "gives to airy nothing / a local habitation and a name". Com isso, não se supõe que a poesia seja reflexo das conceitualizações preceptivas formuladas no supostamente mais "sério" âmbito dos tratados retóricos ou filosóficos; ao contrário, pensa-se, com Michel Foucault, que os discursos têm uma história própria, imbuídos de conceitos próprios que mobilizam. ${ }^{6}$ Nesse sentido, o enunciado preceptivo de Sidney não antecipa ou pré-figura o enunciado poético de Shakespeare, mas são, ambos, pertencentes à atualidade dos discursos, ao mesmo tempo produtos e intervenções em seu presente histórico. ${ }^{7}$ Daí a adequação de ler Sidney para ler Shakespeare, e vice-versa. É preciso notar, sobretudo, que os tratados do século XVI são, em si, peças retoricamente formuladas; para além de um teor "técnico" ou "utilitarista", os tratados, pertencentes como a poesia ao âmbito das representações, encenam nos discursos um viés reflexivo e figurativo. Assim sendo, é interessante ler essas produções historicizando-as, isto é, supondo os regramentos e os condicionamentos retórico-poéticos que não apenas divulgam, mas que encenam na própria tessitura elocutiva. É isso que propõe este artigo ao expor e comentar, em seguida, a produção discursiva sobre poesia e os fazeres miméticos do século XVI inglês. ${ }^{8}$

\section{Das preceptivas retórico-poéticas}

Os letrados ingleses, difundindo tópicas que circulavam nos meios cultos das cortes européias durante os séculos XVI e XVII, escreveram diversos tratados que emulavam e mobilizavam preceitos poéticos e retóricos antigos e contemporâneos. Além de definir as partes da retórica (cinco, três ou duas) e suas funções; de definir a poesia como arte de imitação, e o poeta, aristotelicamente, como eikonopoiós - fazedor de imagens -; estabelecer modelos; preceituar espécies de agudezas; providenciar comentários a figuras e tropos realizados em versos célebres; esses tratados também estabeleciam 
normas que regravam a escrita em vernáculo - da oratória política ou sacra à poesia. De um lado, marcavam sua própria autoridade como emuladores de discursos antigos eleitos como modelos; de outro, superavam na emulação seus modelos antigos em determinados predicados, estabelecendo novas legibilidades para os preceitos convencionados. A metáfora "hortícula" de Antoine Fouquelin, autor de La rhetorique françoise, publicada em 1557, ilustra como os cortesãos do século XVI definiam a emulação de preceitos antigos e sua introdução às línguas vernaculares: "como os bons jardineiros transportam fertilizantes e enxertos de toda parte, a fim de povoar e embelezar os seus pomares, assim também devem ser transferidos ao vernáculo os preceitos das ciências e das artes liberais". 9

Nessa perspectiva, também no reino inglês surgem hipóteses que vão definir questões contemporâneas pertinentes, como, por exemplo, o estabelecimento de modelos de metrificação e rima; a concessão, a Geoffrey Chaucer (1343-1400), do papel de "pai dos poetas ingleses" - embora se fizessem ressalvas quanto à "erudição" de seu vernáculo; e a inclusão das letras inglesas no cenário mais amplo das representações cristãs do continente europeu. $\mathrm{O}$ estudo desses tratados, hoje, indica quais eram os lugares sociais da arte poética segundo os discursos constituídos na época e as doutrinas políticas, teológicas e retóricas que movimentavam (considerando que a produção artística se posiciona frente a diversas exigências culturais/políticas/sociais etc.). À parte isso, o exame desses tratados mostra também as polêmicas críticas levadas a termo entre homens que diputavam a autoridade de determinados lugares de invenção e a reta adequação de opções elocutivas no vernáculo.

A partir da segunda metade do século $\mathrm{XVI}$, há um crescimento vertiginoso do número de preceptivas e tratados impressos ou divulgados em manuscrito. Seus autores são com freqüência (mas não exclusivamente) figuras distintas da nobreza; muitos compõem poesia em vários gêneros, outros são professores de gramática ou tutores da realeza, mas todos estão, de alguma forma, relacionados aos âmbitos da corte e das letras. Como se formula em The Arte of English Poesie, de George Puttenham, seu tratado está explicitamente endereçado "a Cortesãos, para cuja instrução este trabalho foi empreendido". ${ }^{10}$

Em 1535, Leonard Cox publica The Arte or Crafte of Rhetoryke. Professor de gramática com educação em Cambridge e Oxford, Cox afirma ter trazido de suas viagens ao continente preceitos de Erasmo de Rotterdam e de Philip Melanchthon (dois autores que, ao lado de Juan Luis Vives, serviriam como grandes modelos contemporâneos para a constituição do sistema de ensino inglês). ${ }^{11}$ Em 1550, publica-se A Treatise of Schemes and Tropes, de Richard Sherry, o primeiro que providencia uma lista de figuras e tropos em vernáculo, e enumera uma série de vícios e virtudes da elocução. Como apêndice, Sherry traduziu um breve discurso de Erasmo para mostrar como a amplificação (auxesis, no grego, amplificatio, no latim) é capaz de dilatar e decompor, oportunamente, um determinado tópico, e inclui regras para uma composição proporcional, ainda que 
multiforme em suas várias partes. Seus argumentos, além de incidirem sobre o comportamento cortesão (porque definem regras de conversação e estabelecem o que se considera socialmente prudente), cumprem sua função sobretudo no âmbito das letras, em que se formam e se normalizam preceitos para tornar a composição ao mesmo tempo engenhosa (o que pressupõe a agudeza da invenção) e persuasiva (o que pressupõe a clareza relativa da elocução), segundo valores coetâneos. A parte mais interessante do tratado é a sistematização que Sherry faz das figuras retóricas de evidentia, que servem para a descrição de coisas, lugares, pessoas, seguindo as circunstâncias dadas em Cícero. Lembrando que a produção poética do século XVI é, na própria gênese, concebida em termos de gênero poético e/ou retórico, as figuras de evidentia ou descriptio formam um estoque de lugares-comuns apropriados a determinadas tópicas. Ver, a propósito, como "coincidem" as imagens poéticas que descrevem tempestades, jardins, hortas, altares, conjuntos arquitetônicos etc. em diferentes poetas da época. ${ }^{12}$

Em 1553, Thomas Wilson publicou The Arte of Rhetorique ${ }^{13}$, uma obra mais ampla, tida como o primeiro grande tratado de retórica em inglês e vastamente consultada. Wilson enumera as regras mestras para a eloqüência, seguindo Quintiliano, Cícero e a Retórica a Herênio; como Sherry, também inclui a tradução de uma epístola de Erasmo, em que a persuasão é tópica central. Gabriel Harvey, poeta inglês e professor de retórica antiga na Universidade de Cambridge, onde estudou, possuía um exemplar da arte retórica de Wilson, na edição de 1567. Completamente anotado e grifado, o exemplar de Harvey mostra, em uma das marginalia, a importância do tratado, colocando-o ao lado de grandes autoridades do gênero: "Um de meus favoritos sobre a arte de burlar: ao lado de Túlio [Cícero], Quintiliano, O Cortesão em italiano, o quarto capítulo de mensa philosoph. De todos, o mais sucinto, e o mais versado, nosso Wilson". ${ }^{14}$ Wilson, expoente do ciceronianismo da primeira metade do XVI, desempenhou papel de relevo no âmbito das letras na Inglaterra. Teve formação nas universidades de Pádua e de Carrara, e trouxe desses lugares diversos preceitos ainda não sistematizados em inglês (embora esses preceitos pudessem ser lidos por ingleses diretamente em latim, italiano etc.). Publicou, em 1550, The Rule of Reason, conteyning the Arte of Logike, o primeiro tratado sobre lógica escrito em vernáculo, e traduziu três orações de Demóstenes, também pela primeira vez em inglês. Gabriel Harvey, que também possuía um exemplar da lógica de Wilson, anotou na página do índice: "Grande variedade de retórica, lógica e muitos outros saberes". ${ }^{15}$. Em 1577, surge The Garden of Eloquence, de Henry Peacham, que preceitua para a elocução imitando o tratado de Sherry e, assim, estabelece o início da produção de preceptivas inglesas auto-referentes.

Porém, a obra que talvez interesse mais a quem estuda a poesia inglesa dos séculos XVI e XVII - por sua divulgação mais ampla na corte e variedade de tópicos - é o tratado de vasto alcance de George Puttenham, The Arte of English Poesie, publicado em 1589 (mas já circulava em manuscrito pelo menos vinte anos antes). Além de dispor metaplasmos (figuras no nível fônico), figuras elocutivas e tropos segundo o modelo 
corrente da Retórica a Herênio, o preceptista insere no cenário inglês (regrando-os em vernáculo) diversos preceitos para a produção da locução engenhosa que já circulavam no continente, citando copiosamente os italianos e os franceses. A partir da obra de Puttenham, percebe-se que certas eleições passam a integrar de maneira sistemática os escritos sobre poesia e retórica na época. Assim, Francisco Petrarca figura como grande "mestre" da poesia moderna, ao lado de Dante e Ariosto; Geoffrey Chaucer passa a ocupar, como se disse acima, o posto de "pai" da poesia inglesa, ao lado de John Gower (1330-1408) e John Lydgate (1370-1451); Aristóteles, Horácio, Cícero e Quintiliano são as autoridades máximas em questões de retórica e oratória; Homero e Virgílio competem pela comenda de maior poeta épico; a metáfora segue sendo o tropo preferido e o mais belo de todos, sendo desse modo objeto de grande teorização e refinamento; o treinamento do engenho (wit) na sutileza é o que garante ao poeta distinção, porque o engenhoso acha argumentos escondidos e efetua agudezas; entre os poetas ingleses contemporâneos, elege como os mais cultos "Sir Philip Sydney, Sir Walter Rawleigh, Master Edward Dyar, Maister Fulke Greuell"16, entre outros. Propôs, inclusive, traduções para o inglês de figuras e tropos sempre referidos, antes, em grego ou em latim. E, quando os refere, dá exemplos de versos de poetas antigos e contemporâneos, e conta casos de agudezas verbais, por exemplo, tirados de notícias envolvendo o imperador Carlos V, ou de personagens nobres do reino inglês; ou então recita e recicla casos contados por autoridades antigas. Procedendo dessa forma, o autor faz circular no vernáculo matérias e casos comuns antes circunscritos a textos gregos e latinos; a ampliação do conhecimento retórico-poético, através da ampla circulação de tratados como o de Puttenham, é central para a chamada "vulgarização" de tópicas e técnicas antigas não apenas no âmbito das letras "renascentistas", mas também da pintura, por exemplo. ${ }^{17}$

Puttenham, como outros, lança mão do lugar comum contemporâneo que gira em torno da legitimação da poesia vernacular, empreendendo uma defesa da poesia inglesa, e considerando-a uma arte à altura da grega e latina. ${ }^{18}$ Os argumentos centrais, nesse caso, são a copiosidade da língua (virtude para a elocução) e o engenho cultivado dos poetas (virtude para a invenção), que em nada ficariam devendo aos antigos:

E se a arte da Poesia não é outra coisa senão uma técnica que concerne à dicção, por que não seria o mesmo conosco que com os antigos, sendo nossa língua não menos copiosa, vigorosa e significativa do que a deles, nossos conceitos os mesmos, e nossos engenhos não menos aptos a inventar e imitar do que os deles? ${ }^{19}$

O mesmo argumento será usado e repetido exaustivamente durante toda a segunda metade do século XVI. Veja-se, por exemplo, a formulação idêntica do tratadista Ralphe Lever para justificar não já a poesia vernacular, mas um tratado sobre lógica em vernáculo:

Para provar que a Arte da Lógica pode ser ensinada em inglês, eu raciocino assim: primeiro, nós ingleses temos engenho, assim como homens de outras nações o têm: pelo qual concebemos aquilo que tem lógica, e está bem feito, e aquilo que assim 
parece ser, mas não é. Também modelamos para nosso uso uma língua, pela qual expressamos por voz ou escrita todos os inventos que concebemos em nossa mente. ${ }^{20}$

No entanto, o acolhimento da poesia vernacular não era uma questão fechada na época para todo e qualquer caso; o tutor da rainha Elisabeth I, Roger Ascham, por exemplo, sustentou o uso do latim para toda escrita culta, incluindo aí a poesia: "nas línguas grega e latina, as únicas línguas cultas mantidas não na fala comum mas em livros privados, encontramos sempre sabedoria e eloqüência, boa matéria e boa elocução, como nunca ou raramente em outra língua". ${ }^{21}$ Tal orientação serviu durante muito tempo para a preservação do ensino de latim - e, com menor intensidade, de grego - nas escolas de gramática do reino inglês, fazendo com que os poetas da língua dominassem os autores e as obras greco-latinos mesmo sem freqüentar as universidades (é o caso, por exemplo, de Shakespeare ${ }^{22}$ ).

Sir Philip Sidney, em The Defense of Poesy, obra publicada em 1595, também advoga em favor dos poetas, mas ainda em outra questão. No caso, combate o desmerecimento do gênero lírico-amoroso, levado a cabo por alguns que queriam restringir a matéria poética a tópicas religiosas ou filosófico-morais. Os embates entre filósofos e teólogos, de um lado, e gramáticos, retores e poetas, de outro, são antigos, e emulados nesse período. Como disse acima, a produção artística está sempre atendendo a diversas exigências. Há ainda o puritanismo teológico-político no Parlamento inglês, que se colocava em oposição à poesia e às artes imitativas em geral; um exemplo é o tratado de Stephen Gosson, The School of Abuse, de 1579, dedicado a Sir Philip Sidney. ${ }^{23}$ Neste, a lírica amorosa vernacular é vista como inimiga das virtudes cristãs, porque formula sofismas e afeta veracidade em suas invenções fantasiosas:

Arranca a viseira com a qual os Poetas se mascaram, e desvelarás sua vergonha, revelarás sua vaidade, detestarás sua libertinagem, lamentarás sua loucura, e perceberás que suas agudezas devem ser como pérolas em estrume, doces pinturas em telas podres, como castas esposas adornadas de vis cortesãs. [...] Não supreende que Platão os tenha expulsado de sua escola e os tenha banido por completo de sua república, como escritores afeminados, membros sem proveito e absolutos inimigos da virtude. $^{24}$

A censura de Gosson - e de outros que sustentam o mesmo discurso contra as artes imitativas - provoca uma série de reiterações do valor da imitação, como base sobre a qual se erguirão as defesas da poesia culta vernacular. Por esse motivo, é relevante fazer uma exposição sobre o entendimento de imitação - de um lado, a mímesis grega; de outro, a imitatio latina - nos séculos XVI e XVII, para que depois se compreenda um princípio básico que rege a poesia do wit: a emulação.

\section{Mímesis e emulação}

No século XVI, a crença de que a eficácia do poema evidencia a aptidão do engenho (wit) do artíficie e a adequação do estilo ao gênero está estreitamente associada ao fato 
de que a poesia é tida como imitação regrada, artificiosa, conforme aparece formulado desde os antigos. No capítulo XXV da Arte Poética de Aristóteles, encontra-se a célebre preceituação, retomada pelas preceptivas e reiterada com freqüência no século $\mathrm{XVI}$ : "Sendo o poeta um imitador, como o é o pintor ou qualquer outro criador de figuras [eikonopoiós], perante as coisas será induzido a assumir uma das três maneiras de as imitar: como elas eram ou são, como os outros dizem que são ou como parece serem, ou como deveriam ser". ${ }^{25} \mathrm{O}$ poeta se distingue do historiador porque, em vez de narrar fatos acontecidos, considera o que poderia acontecer ou o que poderia ter acontecido, formulando o verossímil; se Heródoto tivesse escrito em versos, como ensina Aristóteles, sua obra não deixaria de ser história, porque, aplicando enunciados de existência, sua invenção não pertenceria ao âmbito da fantasia poética. ${ }^{26} \mathrm{~A}$ preceptiva inglesa emula esse e outros preceitos, defendendo, ora em termos aristotélicos, ora segundo outras autoridades antigas, a poesia vernacular que agora se tem como "culta", seguidora de modelos autorizados. Assim, encontram-se diversos trechos em que os preceptistas argumentam em favor da imitação e do artifício, percebendo e formulando, de forma aguda, que não há nada mais propício para os homens discretos do que empregar seu engenho exercitado nas sutilezas - dom divino, em chave cristã - para imitar e inventar obras engenhosas. Como o alquimista que transforma pedra em ouro, o poeta fabrica o artificial valioso.

Como foco de extensa consideração, aparece a divisão entre as duas formas de arte da imitação formulada por Platão no Sofista: a de se produzir a imagem icástica (eikastikē) cópias feitas em conformidade com o modelo, e portanto supostamente proporcionais - e a imagem fantástica (phantastikē) - simulacro desproporcional, que se distancia do modelo copiado (ainda que almeje a beleza, essa imagem é enganosa e, portanto, não instrui). Platão preceitua que a primeira forma de imitação gera a arte verdadeira, enquanto a segunda produz o falso, o enganoso: "Pois os artistas, deixando a verdade a cuidar de si mesma, de fato inserem nas imagens que constroem não as proporções reais, mas aquelas que parecerão belas". ${ }^{27}$ Nas preceptivas inglesas, como não há o desejo de negar Platão, essa regra aparece redefinida, atendendo a critérios outros. Puttenham propõe outra legibilidade da conceituação de imagem fantástica, assimilandoa a preceitos de Aristóteles e ao ut pictura poesis de Horácio: daí, advoga que há método para se compor poesia segundo preceitos de adequação, proporção e verossimilhança que, se não atendidos, levam ao monstro disforme - invenção de imagens desordenadas e portanto inverossímeis; elocução inartificiosa ou indecorosa - ou à deformidade proporcional: "às pessoas como que iluminadas pelas mais esplendorosas irradiações do conhecimento e da verdade e da reta proporção das coisas, chamam-nas os cultos não 'phantastici', mas 'euphantasiote', e dessa espécie de fantasia é todo bom Poeta". ${ }^{28}$ Se o poeta inventa imagens que parecerão uniformes mesmo em sua multiformidade, segundo o preceito perspectivista horaciano, então produz um todo proporcional, que promoverá o deleite do leitor. Se passadas através do espelho ou vidro do intelecto, essas imagens vão revelar que não são falsas, ainda que aparentemente 
desproporcionais, pois, vistas pelo ângulo adequado do gênero e de seu decoro, adquirirão sentido na agudeza perspectivada do conjunto. ${ }^{29}$

Pressuposta nesse discurso está a noção do poeta "judicioso" - outro conceito-chave dos discursos sobre as artes no século XVI -, que sabe definir na própria composição a legibilidade exigida do poema, suspendendo uma leitura inadequada ou inverossímil: "o poeta discreto não procura favores extraordinários". ${ }^{30}$ Assim como o poeta e seus leitores, o preceptista deve ser igualmente discreto e judicioso, sabendo discernir a fantasia justa e proporcional daquela que não o é, e classificar adequadamente cada caso: "Até mesmo a parte fantástica do homem (se não for desordenada) representa as melhores, mais adequadas e belas imagens ou aparências das coisas para a alma, e de acordo com a verdade delas". ${ }^{31}$ Dessa forma, Puttenham desqualifica os censores da poesia que, por ignorância própria, segundo ele, confundem os poetas phantastici com os euphantasiote (sic), ou seja, aqueles que inventam o fantástico desproporcional e aqueles que produzem a fantasia medida. Destaca-se o passo reproduzido a seguir, em que Puttenham contrapõe, por meio da intensa ridicularização do tipo vulgar, a conceituação do discreto exercitado nas sutilezas tão freqüente nos discursos dos séculos XVI e XVII:

as mentes grosseiras, não familiarizadas ou habituadas com qualquer Arte excelente, $\mathrm{e}$ nem aptas a cogitar ou de maneira alguma conceber certo nível de sutileza em qualquer comércio ou ciência, vão zombar e escarnecer disso em outros como se fosse conhecimento supérfluo e vã ciência, e a toda concepção de rara invenção vão pôr o nome de 'fantástica'. ${ }^{32}$.

Ademais, o preceptista advoga com base em Aristóteles que sem a fantasia não haveria como produzir a "novidade", entendida como emulação culta das autoridades previstas para cada gênero poético. Assim também entende o poeta italiano Geraldi Cinthio: "[Aristóteles] assim nos ensinou que o não-verdadeiro deve ser concebido, já que o maravilhoso daí se origina". ${ }^{33}$ Ficando a encargo dos juízes contemporâneos o aplauso ou a condenação de um poeta, haverá divergências de apreciação, sempre pressupondo doutrinas análogas e o mesmo sistema de representação de fundo aristotélico. Por exemplo: enquanto a maior parte dos juízes de John Donne considera suas invenções proporcionais, outros censurarão alguns versos, como veremos em breve, por gerarem agudezas obscuras e, assim, um todo inverossímil. Como mostra bem o caso das diatribes entre Luis de Góngora y Argote e Francisco de Quevedo, haverá espaço para que se formem juízos de que as imagens fantásticas do cordobês são representações do monstrum horaciano ou provas de um grande engenho, ao qual se devem erguer estátuas. $^{34}$ Assim, a função do discreto judicioso tem implicações políticas, pois determina, no combate discursivo, o que vale ou não no âmbito das letras cultas dos séculos XVI e XVII. E exerce função prescritiva, porque determina os lugares de insulto (decorosos nos gêneros baixos) e de louvor (decorosos nos gêneros altos), reforçando a adequação inventiva e elocutiva do gênero epidítico. 
Sir Philip Sidney aplica outra legibilidade da distinção platônica entre o icástico e o fantástico. Primeiro, faz a conceituação de imitação conforme Aristóteles e Horácio: "A poesia é uma arte de imitação, pois assim a nomeou Aristóteles com sua palavra 'mímesis', isto é, representar, contrafazer ou figurar além - dizendo-o metaforicamente, uma pintura falante -, com este propósito: ensinar e deleitar". ${ }^{35}$ Quando quer afastar as acusações dos misomousoi (poet-haters, como qualifica Gosson) de que poesia é imitação sem valor, Sidney lembra que terá de explicar a conceituação platônica acerca das artes miméticas: "Eis que agora o meu encargo é de fato imenso; agora, o nome de Platão é chamado contra mim". ${ }^{36}$ Ao contrário do que aparece em Puttenham, não há defesa do fantástico na poesia culta; veicula o entendimento de que a verdadeira poesia é sempre de ordem icástica. Dessa forma, Sidney reduz a distinção platônica a apenas uma questão: a de poesia regrada ou desregrada, amalgamando a conceitualização aristotélica de mímesis com a eikonopoiésis. ${ }^{37}$ Para ele, os poetas contemporâneos objetos de sua deliberação sobre poesia - que compõem agudezas obscuras, incapazes de instruir, não podem ser tomados como exemplo ou parâmetro para um julgamento discreto da poesia vernacular. ${ }^{38}$ Por outro lado, aqueles que compõem poesia regrada para Sidney, isto seria a correta imitação, de ordem icástica, isto é, "verossímil" - devem ser louvados e imitados, porque instruem além de deleitar. Assim, oferece a definição de poesia eikastikē: "figurar boas coisas", e de poesia phantistikē: "a que, ao contrário, infesta a mente com objetos ignóbeis". ${ }^{39}$

A maneira sistêmica com que Sidney conceitua a mímesis, isto é, advogando a arte imitativa ora referindo-se a Platão, ora a Aristóteles, faz com que, por fim, sobreponha o estilo médio a outros estilos, pois aquele de fato visa à instrução com deleite. Seguindo Quintiliano, Sidney qualifica os dialógos platônicos como poéticos: "já que, de todos os filósofos, ele é o mais poético" ${ }^{\prime 4}$, e levanta trechos em que a elocução evidencia o emprego de figuras e tropos, demonstrando que o filósofo não poderia estar contra a poesia. ${ }^{41}$ Defendendo o estilo médio, Sidney reitera qualidades das artes imitativas já autorizadas pelos discursos correntes, propondo novas legibilidades sem ferir o antigo paradigma prescritivo. $\mathrm{O}$ interesse de sua preceptiva reside particularmente na defesa eloqüente que faz da prática poética vernacular nos meios letrados ingleses, emulando com eficácia os lugares-comuns de argumentação produzidos em textos das cortes continentais: "que a poesia, bem acolhida em todos os outros cantos, devesse encontrar em nossa época má acolhida apenas na Inglaterra, penso que até a terra se lamenta disso, e então provê nosso solo de menos lauréis do que era antes de costume". ${ }^{42}$ Colocando a poesia inglesa a par do que estava sendo praticado nos meios letrados de outras cortes, Sidney forja um lugar de urbanidade equivalente às contrapartes continentais, abrindo caminho para que essa prática seja continuada por outros. Elegendo a mansão de sua irmã, a condessa de Pembroke, como âmbito cortesão adequado para a prática letrada, Sidney inventa, na Inglaterra, um lugar análogo à "corte de Urbino" de Baltassare Castiglione. A partir desse referencial constituído no discurso, diversos poetas vão eleger a condessa de Pembroke e seu reduto letrado como lugar adequado para suas representações de diálogos cultos. 
Ao lado das defesas da arte mimética em si, isto é, da poesia como arte legítima de imitação, há ainda uma outra categoria orientadora da prática poética dos séculos XVI e XVII: a conceituação latina da imitatio como emulação de casos retóricos, lugares de invenção, elocução adequada segundo gêneros, estilos etc. Seguindo Quintiliano, Dionísio de Halicarnasso, autores das cortes continentais e outros, os preceptistas ingleses normalizam a noção de que toda prática representativa é necessariamente emulativa, pois tem por base genésica um elenco pré-estabelecido de autores que determina os modelos de cada gênero poético e os procedimentos de adequação, como decoro e verossimilhança. O preceptista greco-bizantino Dionísio Longino, em De Sublimitate (Do Sublime) - obra lida na versão latina durante o século XVI -, preceitua enfaticamente a imitação dos antigos: "A imitação zelosa dos grandes autores de prosa do passado. Essa é a meta, grande amigo; apeguemo-nos a ela com todo o nosso esforço"43; e ainda neste passo: "A emulação trará aqueles grandes personagens diante de nossos olhos". ${ }^{44}$ Geraldi Cinthio, sobre a emulação, postula: "[o poeta] deve seguir a trilha de outros não como um escravo, mas como aquele que, preservando seu poder, não se desvia do que é essencial para se escrever artisticamente, como é o costume de bons poetas". ${ }^{45}$ Roger Ascham, em seu manual de gramática e retórica The Scholemaster, de 1570, primeiro formula a conceituação da mímesis aristotélica:

Imitação é faculdade de expressar vivamente e perfeitamente aquele exemplo que se vai seguir. Por si mesma é grande e vasta: pois todas as obras da natureza de certa forma são exemplos para a arte imitar. ${ }^{46}$

Em seguida, faz distinção entre mímesis e imitatio. O primeiro caso remete às considerações expostas acima, como aparecem em Platão, Aristóteles e no ut pictura poesis de Horácio. O segundo caso concerne à emulação de autoridades gregas e latinas:

O segundo caso de Imitação é seguir os melhores autores para o aprendizado de doutrinas e de línguas estrangeiras. Aqui se levanta entre os engenhos orgulhosos e invejosos uma grande controvérsia: se apenas um autor ou, pelo contrário, muitos autores devem ser seguidos; e, caso apenas um, quem: Sêneca ou Cícero?, Salústio ou César?, e assim por diante entre os gregos e latinos. ${ }^{47}$

Ascham preconiza que a rudeza do vernáculo se beneficia da imitação de autores antigos, pois argumenta que não possui autoridade própria, sendo uma língua vulgar sem um passado culto:

[...] Se quiseres falar como os melhores e mais sábios, deve ter familiaridade com os melhores e mais sábios; mas, se tiveres nascido ou crescido em um país inculto, não podes escolher senão falar incultamente. Os homens mais incultos que há sabem ser isso verdade. No entanto, a rudeza das línguas comuns e maternas não é impedimento para se falar sabiamente; pois no mais inculto dos países e na língua mais bárbara, muitos há que falam sabiamente. Mas nas línguas grega e latina, as únicas línguas cultas mantidas não na fala comum mas em livros privados, encontramos sempre 
sabedoria e eloqüência, boa matéria e boa elocução, como nunca ou raramente em outra língua. ${ }^{48}$

O enunciado de Ascham evidencia que a prática da emulação de autores antigos tem um fundamento doutrinário análogo na Inglaterra e em reinos continentais europeus, pois o vernáculo não permite auto-referência exclusiva nos meios cultos das práticas letradas.

Uma objeção possível a essa inferência é que os italianos do século XVI já tinham Dante e Boccaccio; os espanhóis, o Cantar de mío Cid, os romances de cavalaria e Gonzalo de Berceo; os franceses tinham François Villon e os provençais; os ingleses, Chaucer e Lydgate; os portugueses, as canções trovadorescas, etc. $\mathrm{O}$ argumento autorizador de um vernáculo pré-existente e praticado em poesia será usado amplamente por preceptistas e poetas do século $X V I$, com objetivos específicos. Porém, os próprios autores eleitos no século XVI como representantes de um "passado da língua" não serão autorizados como parâmetro incondicional para imitação, mas circunstancialmente, como casos singulares de autores que, antes do século XVI, já cultivavam o vernáculo (embora com um regramento diferente) com a imitação de modelos antigos. Assim, Sir Philip Sidney reconhece a excelência inventiva de Chaucer, mas faz ressalvas sérias quanto à elocução: "Chaucer, sem dúvida, é excelente em seu 'Troilus and Criseyde' [...]. Ainda que tivesse grandes faltas, perdoáveis apenas por pertencerem a um passado remoto". ${ }^{49}$ E também no caso do espanhol Amadís de Gaula: "Que só Deus sabe o quanto lhe faltava em perfeição poética". . $^{0}$

Quando um poeta engenhoso da corte inglesa era chamado para justificar sua invenção poética, raramente a autorizava citando versos de Chaucer. Para a prática de emulação, valem os gregos e latinos e os poetas continentais que já emulavam os antigos Garcilaso, Petrarca, Ariosto, etc. Sob essa perspectiva, argumenta-se que a poesia vernacular culta das cortes cristãs dos séculos XVI e XVII seguia um elenco variável porém autorizado para a imitação (considerando a entrada gradativa de modelos que alargavam as possibilidades de estilo, promovida pelas novas edições de autores antigos que ocorria nos meios cultos) e também pressupostos doutrinários muito análogos, pois estes advinham direta ou indiretamente de textos antigos autorizados para a prática de emulação nos vernáculos. Tanto John Donne quanto os poetas da agudeza de reinos continentais afirmavam emular, antes, o obscuro Lícofron do que, por exemplo, Chaucer ou mesmo Dante. Giraldi Cinthio, embora reconheça a excelência do tópico casuístico na Divina Comédia, faz ressalvas quando trata do tópico elocutório: "Prefiro, nesse caso, não discutir Dante, pois, ou por culpa de seu tempo ou de sua própria natureza, tomou tamanhas liberdades que sua licensa se tornou vício". ${ }^{51} \mathrm{Na}$ preceptiva do século XVI, a emulação de lugares de invenção antigos e de lugares contemporâneos que emulavam antigos também acontecia, de forma análoga ao que ocorria na prática poética. Tome-se, por exemplo, o elenco citado por Sidney para autorizar seu argumento de que a poesia é arte legítima de imitação e que se deve crer nas autoridades - Aristóteles, Bembo, Escalígero, Clausero, Landino - quando dizem que os poetas sempre foram os baluartes de tudo o que é divino e culto: 
[...] crer, com Aristóteles, que [os poetas] foram os antigos guardiões do tesouro da divindade grega; crer, com Bembo, que foram os primeiros a trazer toda a civilidade; crer, com Escalígero, que nenhum preceito de filósofo pode tornar honesto um homem como a leitura de Virgílio; crer, com Clausero, o tradutor de Cornuto, que agradava à celeste divindade, por meio de Hesíodo e Homero, sob o véu de fábulas, dar-nos toda ciência, lógica, retórica, filosofia natural e moral; e, por que não?, crer, comigo, que há muitos mistérios contidos em poesia, que com propósito foram escritos obscuramente, para que engenhos profanos não fizessem deles mau uso; crer, com Landino, que são tão amados pelos deuses que tudo o que escrevem provém de fúria divina. ${ }^{52}$

Como Quintiliano e outros, também os ingleses previam os limites da emulação, desvalendo a cópia sem acréscimo, ou seja, a imitação sem novidade. Roger Ascham, por exemplo, preceitua: "Essa Imitação é dissimilis materiei similis tractatio: e, também, similis materiei dissimilis tractatio, como Virgílio seguiu Homero: mas o Argumento, para o último, foi Ulisses, para o primeiro, Enéias" ${ }^{53} \mathrm{O}$ entendimento de Ascham espelha o de tratadistas continentais, que defendem a imitação dos modelos antigos na poesia vernacular com a variação nos argumentos e a variação elocutiva, sem que se constitua "roubo". Veja-se o caso, por exemplo, da defesa que o espanhol Francisco Sánchez de las Brozas fez, na segunda metade do século XVI, da imitação praticada por Garcilaso de la Vega, em sua edição comentada da obra de seu conterrâneo:

Dizer que com esses comentários se faz maior afronta ao poeta do que honra, pois por eles se descobre e revela o roubo, que antes estava escondido, seria certamente uma opinião não merecedora de resposta, se estivéssemos falando com os mais sábios. Mas, para satisfazer aqueles que não o são, digo e afirmo que não tomo por bom poeta o que não imita os excelentes antigos. E se me perguntam por quê, dentre os muitos milhares de poetas, a nossa Espanha conta apenas com poucos desse tipo, eu digo que não há outra razão senão faltarem-Ihes conhecimento, línguas, doutrinas e saber como imitar. ${ }^{54}$

Isto é, se o comentador apresenta os passos em que Garcilaso tira matéria a partir dos lugares de invenção antigos, a descoberta é mais digna de aplauso que de censura, pois demonstra a erudição do poeta e sua aptidão para a prática imitativa; a quem não entende assim, falta discrição e juízo para discernir emulação de "roubo".

Desse modo, na poesia vernacular, a imitação de modelos antigos, o regramento retórico da invenção e da elocução, a adequação do estilo pela matéria de que o poema trata, segundo convenções de gênero ou de novas legibilidades justificadas pelo uso, são práticas previstas na poética dos séculos $\mathrm{XVI}$ e XVII, deixando pouco espaço para que se pense em "originalidade" ou outras categorias românticas e pós-românticas de apreciação estética. É justamente pela emulação dos antigos que a poesia vernacular se constitui como prática poética autorizada, pois a distinção essencial que terá em relação a seus modelos tange questões não necessariamente da excelência da invenção ou de regramento pela retórica, mas de adequação lingüística considerando os vernáculos. ${ }^{55}$ 
Tratando da emulação, a pesquisadora Rosemund Tuve, em The Elizabethan Imagery, argumenta que não havia, no século XVI, a cisão romântica e pós-romântica de forma e conteúdo, e nem a separação sentenciosa entre o natural e o artificial:

O poeta que imita não o mundo visível, mas o inteligível enquanto manifesto no visível, não considera que o uso de artifício para enfatizar a forma tornaria a imagem menos fiel à natureza; [...] a imagem renascentista pode ser extremamente e cuidadosamente artificial sem ser tida por irreal, não natural ou mera decoração. ${ }^{56}$

Nas preceptivas do século XVII, o termo "artificial" aparece como relativo a "artífice", porque, seguindo o entendimento aristotélico, o poeta é um "fabricador", isto é, aquele que cria com artifício. Assim começa o tratado de Puttenham: "Dizer 'um Poeta' é o mesmo que dizer 'um fazedor'. E nossa palavra em inglês está bem conforme com o grego: pois de poiyin, fazer, os gregos chamam o fazedor de Poeta". ${ }^{57}$ Por isso Sidney, quando censura a poesia que não segue os preceitos aristotélicos ou horacianos de imitação, diz que resulta em algo "inartificially imagined" ${ }^{\text {" }}$; infere-se daí que seria inadequado, para Sidney, o poema não ser trabalhado artificiosamente, porque poderia apenas resultar em algo descuidado e, então, vulgar e impossível de ser compartilhado. Na definição de retórica de Thomas Wilson, há a mesma compreensão do termo: "uma declaração artificial da mente" ("an artificial declaration of the mind"). ${ }^{59}$ No dicionário francês-latim de Robert Estiénne, de 1539, o "engenhoso" é "arguto" e "artificioso": "Ingenieu: qui ha bon espris \& entendement. Argute. Artificiose. Acute". ${ }^{60}$ No centro dessa questão está o entendimento de que o "natural" como "autêntico" e o "artificial" como "afetação" não são categorias correntes no século XVI. A conceituação de "poeta" não pressupõe um tipo humano que expresse coisas subjetivas, idéias próprias ou devaneios inspirados. Como afirma o crítico John Buxton acerca dos poetas seiscentistas, "Eles não buscavam originalidade, e nem entenderiam o significado de 'auto-expressividade' - ou, se acaso entendessem, teriam recusado o conceito como algo fácil, vulgar e, portanto, asqueroso". ${ }^{61}$ No entanto, parte da crítica moderna tem ainda interpretado os poemas de John Donne, por exemplo, como auto-expressivos e não-imitativos, anacronicamente. Quando querem enaltecer Donne como monarca do wit, muitos têm se dedicado à tarefa de retirá-lo, ou mesmo "resgatá-lo", da suposta "artificialidade" (no pejorativo) de seu meio. É bastante citado, na crítica, este enunciado de Virginia Woolf sobre Donne:

O elisabetano típico, com seu amor pela eloqüência, com seu anseio por admiráveis novas palavras, tendia a amplificar e generalizar [...]. O gênio de Donne era precisamente o oposto disso. Ele diminuía; particularizava [...]. É esse desejo de nudez em uma época florida, é essa determinação de registrar não as semelhanças que tornam uma composição um todo redondo e agradável, mas as inconsistências que dissolvem similaridades [break up semblances], é o poder de nos fazer sentir emoções diferentes de amor e ódio e de riso que separam Donne de seus contemporâneos. ${ }^{62}$

Não é fácil inferir quem seriam esses "contemporâneos" de Donne referidos no texto. Como se aprende com Baltasár Gracián, em Agudeza y arte de ingenio, as agudezas efetuadas por dissonância, disparidade e equívoco, por exemplo, têm justamente a qualidade de "break up semblances", e foram praticadas por diversos coetâneos de 
Donne. A inadequação interpretativa, aqui, é provocada pela eleição artificiosa (nesse caso, no sentido pós-romântico do termo) de apenas uma espécie de agudeza como representativa de toda a poesia do wit na Inglaterra dos séculos XVI e XVII. Maior equívoco, ainda, é determinar que essa única espécie de agudeza seja denotativa de um "traço nacional", de um "wit inglês". Nessa chave, aparta-se Donne não apenas de seus conterrâneos na agudeza (como Fulke Greville, George Chapman, Bishop King, Walter Ralegh, e outros que desenvolveram gêneros diversos), como também de seus contemporâneos lato sensu.

A prática anacrônica, evidentemente, não se restringe ao julgamento de poetas, como se infere da apreciação negativa que André Gide faz, na primeira metade do século XX, da imitação de modelos antigos em Montaigne:

O exibicionismo erudito não era peculiar a Montaigne, nessa época em que a cultura grega e romana ainda subia à cabeça. Observa Gibbon, muito judiciosamente, que o estudo das letras antigas, bem anterior ao início do Renascimento, antes retardou do que fez progredir o desenvolvimento intelectual dos povos do Ocidente. É que em tal estudo se procurava, então, menos uma inspiração e um trampolim do que modelos. A erudição no tempo de Boccaccio e Rabelais pesava sobre as inteligências, e longe de ajudá-las a se libertar, as sufocava. A autoridade dos antigos, e em particular a de Aristóteles, atolava a cultura numa rodeira, e durante o século XVI a Universidade de Paris quase que só formou pedantes e parlapatães. ${ }^{63}$

Observa-se que, na base de tal apreciação estética, reside uma noção teleológica de que as coisas progridem, e que o olhar moderno enxerga, com desprezo, as práticas servis produzidas numa época de repressão à subjetividade. Seria preciso buscar, no pântano da conformidade servil produtora de repetições sem fim, "jóias irregulares" (isto é, algumas idéias de Montaigne; os jogos "lúdico-perversivos" de Donne em The Flea, por exemplo, vistos como subversivos para seu tempo). Assim, a conclusão de André Gide sobre Montaigne:

Montaigne, em sua viagem à Itália, admira-se de encontrar os mais altivos monumentos da antiga Roma não raro semi-enterrados entre escombros. É pelo cimo que eles pouco a pouco se esboroam. Mas seus próprios escombros erguem mais alto o solo que marchamos. E se, em nossos dias, tal ou qual campanário nos parece menos alto é porque o contemplamos de mais baixo. ${ }^{64}$

\section{Uma elegia de Donne pelo viés aristotélico}

Um exemplo adequado para se tratar da noção aristotélica de mímesis e da conceituação latina da imitatio, em John Donne, é a divergência na leitura da preceituação corrente gerada em torno de uma elegia fúnebre encomendada por ocasião do primeiro aniversário da morte de Elizabeth Drewry - filha de Sir Robert Drewry, um dos patronos de Donne. A seguir, um pequeno trecho da elegia, intitulada The Anniversarie: An Anatomie of the World (sua versão integral conta 475 versos) ${ }^{65} \mathrm{e}$ publicada pela primeira vez em 1611: 
If she whom we lament had not beene dead:

But shee, in whom all White, and red, and blew

(Beuties ingredients) voluntary grew,

As in an unvext Paradise; from whom

Did all things verdure, and their lustre come,

Whose composition was miraculous,

Being all colour, all diaphanous,

(For Ayre, and Fire but thick grosse bodies were,

And liveliest stones but drowsie, and pale to her,)

Shee, shee, is dead; shee's dead: when thou know'st this,

Thou knowest how wan a Ghost this our world is. ${ }^{66}$

Inserindo-se no subgênero encomiástico, a elegia de Donne é apologia, e assim formula argumentos de invenção para compor, na fantasia, o mais alto louvor de sua musa (sem se ater aos supostos acidentes particulares da coisa referida). A agudeza de estilo enigmático (observem-se os parênteses que inserem sintagmas nominais, os hipérbatos das orações subordinadas, as figuras de repetição e ênfase que estabelecem o páthos de reverência apaixonada, a doutrina hermética de Marsílio Ficino sobre o intelecto das substâncias, etc), programaticamente causadora de obscuridade, define a legibilidade do texto segundo o gênero e o estilo da composição culta. No entanto, houve quem julgasse, usando os mesmos pressupostos contemporâneos de representação, que Donne foi "afetado" na agudeza, errando como artífice. Trata-se de enunciado proferido pelo poeta Ben Jonson, em que acusa a inadequação da invenção de Donne, geradora de um todo desproporcional. Como relata o amigo William Drummond, Jonson teria feito a acusação da inverossimilhança da invenção:

[Disse] que o Anniversary de Donne era profano e cheio de blasfêmias. Que disse a Donne que se o poema fosse sobre a Virgem Maria, faria algum sentido; e que Donne Ihe respondeu que descrevera a idéia de uma mulher, e não como ela era. ${ }^{67}$

Respondendo à acusação, Donne se defende a partir da conceituação aristotélica da mímesis poética, dizendo que não se tratava de descrever a pessoa tal qual ela era (pois nem conhecera a moça), mas sim de formular o verossímil - o que poderia ou deveria $\operatorname{ser}^{68}$ :

Minha defesa é que meu propósito foi dizer tão bem quanto possível: pois, já que nunca vi a Dama, não se podia esperar que eu me restringisse a dizer apenas verdades; mas não se pode pensar que eu, dispondo-me a louvá-la (ou a qualquer outra) em verso, o faria se não considerasse tal pessoa merecedora de tudo o que eu poderia dizer. ${ }^{69}$

O empenho do poeta direcionava-se então a elaborar o elogio como adequação da matéria poética apoiado em normatividades definidas para o gênero epidítico, e também segundo o princípio, corrente no costume cortesão dos séculos XVI e XVII, de que mais se louva quanto mais agudo e obscuro for o poema. A transferência da qualidade engenhosa da composição para o destinatário é um pressuposto da poesia do wit. 
Aristotelicamente (ou na leitura seiscentista de Aristóteles, mais precisamente), a imaginação poética é o elo entre "the poet's eye" e "the poet's pen", conforme vimos nos versos de Shakespeare.

O crítico John Buxton formula uma comparação relevante e efetiva para explicar o caso da censura recebida por Donne em sua época. Relata que William Wordsworth, o poeta romântico inglês, se negou a atender o pedido de um tio para que compusesse uma elegia fúnebre para o reitor de Cambridge (universidade em que estudava), alegando que não poderia expressar sentimentos inexistentes pelo morto. Disse Wordsworth: "Não sentia interesse algum pelo falecido, pois eu nunca estive com ele e nem mesmo o tinha visto". ${ }^{70}$ Buxton mostra, eficazmente, as diferenças fundamentais das categorias definidoras das práticas poéticas correntes nos séculos XVII e XIX:

Tal motivo para recusar-se a compor uma elegia seria incompreensível para Spenser ou Donne como também para o tio de Wordsworth, pois nunca suporiam ser mais necessário a um poeta do que a um escultor de túmulos sentir 'interesse pelo falecido'. Esperava-se, tanto de um poeta quanto de um escultor, que produzissem um objeto adequado para honrar os mortos, e não que se derramassem em lágrimas. Donne nunca havia visto Elizabeth Drury, mas os defeitos em sua celebração das virtudes da moça não derivam, de modo algum, dessa circunstância. Ben Jonson disse a Donne que se o poema 'fosse sobre a Virgem Maria faria algum sentido' - e não que se 'fosse sobre Anne Donne ou Magdalen Herbert', por cujas mortes Donne sentiu uma comoção profunda. $^{71}$

Comparando o poeta ao escultor que ergue o ornamento tumular, Buxton desvincula da função do artífice a auto-expressividade, categoria inativa nos séculos XVI e XVII. A censura de Ben Jonson, prevista para seus contemporâneos, incide sobre questões de adequação poética, apontando uma falha no processamento inventivo enquanto gerador de um todo inverossímil (porque o estilo seria desproporcional à matéria tratada no poema). O enunciado de Donne em que se defende também opera dentro de convenções poéticas correntes, e conta com a autoridade de Aristóteles para se sustentar. Embora o poeta não tenha citado nominalmente a Arte Poética, ele pressupõe, na base de sua defesa, trechos como este, de Aristóteles: "Se o poema contém impossibilidades, há falta; no entanto, isso nada quer dizer, se o fim próprio da arte foi alcançado (fim que já foi indicado) e se, desse modo, tal ou tal parte da obra redundou mais impressionante, como, por exemplo a perseguição de Heitor". ${ }^{72}$

Assim também Sir Philip Sidney; seguindo a conceituação aristotélica, ao lado do ut pictura poesis horaciano, compara o poeta ao pintor que, querendo retratar o lamento de Lucrécia em sua penitência, busca argumentos pertinentes à tópica da virtude, em vez de acidentes constitutivos do objeto louvado. ${ }^{73}$ Giraldi Cinthio, muito agudamente reciclando um topos antigo sobre pintores, narra a anedota de que Leonardo da Vinci teria levado um ano para terminar sua tela da Santa Ceia; tudo estava pronto, exceto a cabeça de Judas. Cinthio explica que o pintor, judicioso artífice, coletou centenas de desenhos que fez a partir de modelos vivos, anônimos vilões que freqüentavam os lugares inóspitos da cidade. ${ }^{74}$ Combinando, na proporção decorosa, a expressão de um 
com a expressão de vários, e a forma do olho de um com a de outros, chegou enfim à imagem que sua faculdade inventiva exercitada havia apreendido como "espelho do vício". Assim, Cinthio autoriza Da Vinci emulando o caso relatado como um lugar-comum da prática imitativa judiciosa. ${ }^{75}$

Se Donne pensava a mímesis aristotelicamente, também no caso da imitatio, isto é, da emulação de modelos previstos para cada gênero, ele seguia a preceituação latina. Como o poeta era um artífice - e não um demiurgo segundo a acepção romântica -, era conveniente que trabalhasse a partir de preceitos cristalizados pela consuetudo, ou o costume vigente adotado nos meios letrados, contemplando o mais possível a sua variedade (o que evidenciava a versatilidade do poeta). Para competir com outros autores engenhosos, Donne devia superá-los, efetuando analogia de analogias, e vencendo-os na novidade dos argumentos e da variação elocutiva.

\section{BIBLIOGRAFIA COMPLEMENTAR}

CROLL, M. W. Style, Rhetoric, and Rhythm. Princeton: Princeton University, 1966.

ELIAS, N. O processo civilizador. Rio de Janeiro: Jorge Zahar, 1993.

FIORUSSI, L. S. No man is an island: John Donne e a poética da agudeza na Inglaterra no século XVII. Tese (doutorado) - Faculdade de Filosofia, Letras e Ciências Humanas da Universidade de São Paulo, São Paulo, 2008, 257 p. Disponível em: http://www.teses.usp.br/teses/disponiveis/8/8147/tde-30032009-161853.

GRIGERA, L. L. Anotações de Quevedo à Retórica de Aristóteles. Campinas: Unicamp, 2008.

KOSELLECK, R. Futuro passado: contribuição à semântica dos tempos históricos. Rio de Janeiro: Contraponto; Ed. PUC-Rio, 2006.

PÉCORA, A. Máquina de gêneros. São Paulo: Edusp, 2001.

SANTOS, M. M. dos. "O Monstrum da Arte Poética de Horácio". In: Letras Clássicas, São Paulo, ano 4, n. 4, 2000, pp. 191-266.

SKINNER, Q.; SCHMITT, C. B. (orgs.). The Cambridge History of Renaissance Philosophy. Cambridge: Cambridge University, 1988.

\section{* Lavinia Silvares Fiorussi é professora adjunta de Literatura Inglesa na UNIFESP.}

Este artigo recebeu apoio financeiro da FAPESP.

${ }^{1}$ Ver, a respeito, a engenhosa discussão entre Gombrich e Peter Burke sobre o conceito de história cultural, disponível no site http://www.gombrich.co.uk/showdoc.php?id=19.

${ }^{2}$ Cf. CERTEAU, M. de. A escrita da história. Rio de Janeiro: Forense Universitária, 2000.

${ }^{3}$ A Midsummer Nights Dream, 5.1.7-12. In: SHAKESPEARE, W. The Complete Works. New York: Gramercy Books, 1975, p. 169. 
${ }^{4}$ In: SHAKESPEARE, W. Sonho de uma Noite de Verão. Tradução de Maria Cândida Zamith. Porto: Campo das Letras, 2002, p. 136.

${ }^{5}$ SIDNEY, P. The Defense of Poesy (1595). In: Sir Philip Sidney - The Major Works. Oxford: Oxford University, 2002, p. 216: "Only the poet [...], lifted up with the vigour of his own invention, doth grow in effect another nature, in making things either better than nature bringeth forth, or, quite anew, forms such as never were in nature, as the Heroes, Demigods, Cyclops, Chimeras, Furies, and such like: so as he goeth hand in hand with nature, not enclosed within the narrow warrant of her gifts, but freely ranging only within the zodiac of his own wit". Todas as traduções do inglês e do francês apresentadas no corpo deste texto são minhas, exceto quando indicado.

${ }^{6}$ Cf. FOUCAULT, M. A arqueologia do saber. Rio de Janeiro: Forense, 1997, p. 146.

${ }^{7}$ A propósito do método de estabelecer cruzamentos entre discursos poéticos e preceptivos sem pressupor a precedência de um sobre o outro - isto é, negando-se o método reflexológico -, ver HANSEN, J. A. A sátira e o engenho: Gregório de Matos e a Bahia do século XVII. São Paulo: Ateliê e Unicamp, 2004, p. 108 et passim.

${ }^{8} \mathrm{O}$ recorte cronológico circunscrito aqui como "Renascença" ou "século XVI" supõe a vigência de um sistema de representação de doutrinas retórico-poéticas, filosóficas e teológicas que dura mais de cem anos. Assim, o escopo temporal deste artigo integra décadas do século XVI e do início do século XVII.

9 "[...] comme les bons iardiniers transportent des gresses \& entes de toutes parts, affin de peupler \& embellir leurs vergers, ainsi ilz eussent transferé en leur vulgaire, les preceptes des sciences \& ars liberaus". La Rhetoriqve Françoise D'Antoine Fovqvelin de Chauny en Vermandois. A Tresillvstre Princesse Madame Marie Royne d'Ecosse. Paris, 1557. Ver o fac-símile do texto original no site da Biblioteca Nacional Francesa, em http://gallica.bnf.fr/ark:/12148/bpt6k506072.

10 PUTTENHAM. The Arte of English Poesie. London: 1589, I, 132: "for Courtiers for whose instruction this trauaile is taken". Ver o fac-símile do texto original no site do Google Books, em: http://books.google.com.br/books?id=vqwUAAAAQAAJ\&pg=PA14\&dq=puttenham.

${ }^{11}$ Cf. KENNEDY. La retórica clásica y su tradición cristiana y secular, desde la antigüedad hasta nuestros días. Tradução de Patricia Garrido e Victoria Pineda. Logroño: Instituto de Estudios Riojanos, 2003, p. 289: "La Rhetoryke de Cox es en parte traducción de las Institutiones Rhetoricae de Melanchthon de 1521 y en parte un comentario de Cox sobre aspectos de la retórica, siguiendo una guía de estudio compilada por uno de los alumnos de Melanchthon".

${ }^{12}$ A pesquisadora Luisa López Grigera mostrou, nesse sentido, que os exercícios de composição (tirados dos progymnasmata de Aftônio e Hermógenes) que integravam os currículos das escolas de gramática do século XVI formavam os alunos na habilidade descritiva de regramento retórico, através das figuras de evidentia e descriptio, formando um "cânone descritivo". Cf. GRIGERA, L. L. La retórica en la España del Siglo de Oro. Salamanca: Universidad de Salamanca, 1994, p. 27.

${ }^{13}$ The Arte of Rhetorique, for the use of all soche as are studious in Eloquence, set forthe in Englishe.

14 STEM, V. F. Gabriel Harvey: A Study of His Life, Marginalia and Library. Oxford: Clarendon Press, 1979, p. 239: "One of my best for the art of jesting: next Tullie, Quintilian, the Courtier in Italian, the fourth of mensa philosoph. Of all, the shortest, \& most familiar, owr Wilson". O enunciado evidencia a prática corrente no século XVI de agrupar autores por gênero de composição e tópicas tratadas.

${ }^{15}$ Ibidem: "Great varietie of rhetorique, logique, \& much other learning".

${ }^{16}$ PUTTENHAM. Op. cit., I, 49.

17 A propósito, ver a importância da "vulgarização" de temas antigos para a obra de Ticiano, conforme argumenta Carlo Ginzburg em "Ticiano, Ovídio e os códigos da figuração erótica no 
século XVI". In: Mitos, emblemas, sinais - morfologia e história. São Paulo: Companhia das Letras, 1986, cap. 4.

${ }^{18}$ Seguindo a prática de autores do continente, em especial italianos e franceses, que desde Dante argumentam a favor da poesia culta vernacular. Cf. Pietro Bembo, Prose della volgar lingua; Giraldi Cinthio, Discorso intorno al comporre dei romanzi; Torquato Tasso, Discorsi dell'arte poetica e del poema eroico; Joachim Du Bellay, La deffence et illustration de la langue françoyse; Martin Opitz, Buch von der deutschen Poeterei; entre outros.

${ }^{19}$ PUTTENHAM. Op. cit., I, 3: "And if th'art of Poesie be but a skill appertaining to vtterance, why may not the same be with vs aswel as with them, our language being no less copious pithie and significatiue then theirs, our concepts the same, and our wits no less apt to deuise and imitate then theirs were?"

${ }^{20}$ LEVER, R. The Arte of Reason, rightly termed, Witcraft, teaching a perfect way to argue and dispute, 1573, The forespeache. Ed. fac-similar. Menston: The Scolar Press, 1972: "To proue that the arte of Reasoning may be taught in Englishe, I reason thus: First, we Englishe men haue wits, as wel as men of other nations haue: Whereby we conceyue what standeth with reason, and is well doone, and what seemeth to be so, and is not. Wee have also framed unto our selues a language, whereby we do expresse by uoice or writing, all deuices that we conceyue in our minde".

${ }^{21}$ The Schoolmaster. Or plain and perfect way of teaching children, to understand, write, and speak the Latin tongue, but specially purposed for the private bringing-up of youth in gentlemen's and noblemen's houses [...], 1570: "in the Greek and Latin tongue, the only two learned tongues which be kept not in common talk but in private books, we find always wisdom and eloquence, good matter and good utterance, never or seldom asunder".

${ }^{22}$ Quem se interessar particularmente pela educação/formação de Shakespeare, ver a magnífica argumentação de BALDWIN, T.W., Shakespere's Small Latine and Lesse Greeke, disponível online no site da Universidade de Illinois: http://durer.press.illinois.edu/baldwin/index.html.

${ }^{23}$ The Schoole of Abuse, conteining a plesaunt inuective against Poets, Pipers, Plaiers, lesters, and such like Caterpillers of a commonwealth [...]. To the right noble Gentleman, Master Philip Sidney, Esquier, Stephen Gosson wisheth health of body, wealth of minde, rewarde of vertue, aduancement of honour, and good success in godly affairs, 1579. Disponível online no site da Universidade de Oregon: http://www.uoregon.edu/ rbear/gosson1.html.

24 "Pul off the visard that Poets maske in, you shall disclose their reproch, bewray their vanitie, loth their wantonnesse, lament their follie, and perceiue their sharpe sayings to be placed as Pearles in Dunghils, fresh pictures on rotten walles, chaste Matrons apparel on common Curtesans. [...] No marueyle though Plato shut them out of his schoole, and banished them quite from his common wealth, as effeminate writers, vnprofitable members, and vtter enimies to vertue".

${ }^{25}$ ARISTÓTELES. Arte poética. Rio de Janeiro: Ediouro, s/d, p. 344. Conferir a tradução inglesa: ARISTOTLE. Poetics. Tradução de Stephen Halliwell. London; Cambridge: Harvard U.P., 1995, p. 125. Cf. a variação que Pierre de Ronsard faz, em 1565, da preceituação aristotélica: "L'inuention n'est autre chose que le bon naturel d'vne imagination conceuant les Idées \& formes de toutes choses qui se peuuent imaginer tant celestes que terrestres, animées ou inanimes, pour apres les representer, descrire, \& imiter: car tout ainsi que le but de l'orateurs est de persuader, ainsi celuy du Poëte est d'imiter, inuenter, \& representer les choses qui sont, qui peuuent estre, ou que les anciens ont estimé comme veritable".

${ }^{26}$ Cf. a variação que Sidney faz da proposição aristotélica, emulando-a: "it is not rhyming and versing that maketh a poet - no more than a long gown maketh an advocate, who though he pleaded in armour should be an advocate and no soldier". Op. cit., p. 347.

${ }^{27}$ Cf. PLATO. Sophist. In: The Collected Dialogues. Princeton: Princeton U.P., 1989, pp. 957-1017, 236, a. 
${ }^{28}$ PUTTENHAM. Op. cit., I, 15: "such persons as be illuminated with the brightest irradiations of knowledge and of the veritie and due proportion of things, they are called by the learned men not phantastici but euphantasiote, and of this sorte of phantasie are all good Poets".

29 "As by a glasse or mirrour, are represented vnto the soule all maner of bewtifull visions". PUTTENHAM. Op. cit., I, 14. Sobre o espelho como representação do intelecto, cf. HANSEN, J. A. "Retórica da agudeza". In: Letras Clássicas, São Paulo, n. 4, 2000, p. 322: "Acredita-se no século XVII que o intelecto humano é um espelho sempre idêntico a si mesmo e simultaneamente sempre vário, que exprime imagens dos pensamentos das coisas postas à sua frente".

${ }^{30}$ PUTTENHAM. Op. cit., I, 16: "the discret poet lookes for no such extraordinary fauors".

31 "Euen so is the phantasticall part of man (if it be not disordered) a representer of the best, most comely and bewtifull images or apparances of thinges to the soule and according to their very truth".

${ }^{32}$ PUTTENHAM. Op. cit., I, 14: "whose grosse heads not being brought vp or acquainted with any excellent Arte, nor able to contriue, or in manner conceiue any matter of subtiltie in any businesse or science, they doe deride and scorne it in all others as superfluous knowledges and vayne sciences, and whatsoeuer deuise be of rare inuention they terme it phantasticall".

${ }^{33}$ CINTHIO, G. On Romances [Discorso intorno al comporre dei romanzi]. Tradução de Henry Snuggs. Lexington: University of Kentucky, 1968, p. 49: "[Aristotle] therefore taught us that the untrue ought to be feigned, since the wonderful originates from it".

${ }^{34}$ Uma seleção de cartas e textos que integram a acirradíssima disputa seiscentista sobre o valor da poesia de Góngora se acha em ARANCÓN, A. M. (org.). La batalla en torno a Góngora. Barcelona: Bosch, 1978.

${ }^{35}$ SIDNEY. Op. cit, p. 217: "Poesy is an art of imitation, for so Aristotle termeth it in his word mimesis, that is to say, a representing, counterfeiting, or figuring forth - to speak metaphorically, a speaking picture - with this end, to teach and delight".

${ }^{36}$ Ibidem, p. 238: "But now indeed my burden is great; now Plato's name is laid upon me".

${ }^{37}$ Notar, a respeito, que as disputas entre platônicos e aristotélicos no século XVI não raro tendem a um amálgama de conceitualizações que compartilham uma base análoga "de fundo", como diz Cassirer sobre os italianos do fim do século XV. Cf. CASSIRER, E. Indivíduo e cosmos na filosofia do Renascimento. São Paulo: Martins Fontes, 2001, p. 6.

${ }^{38}$ Sidney é partidário de um estilo agudo suave em poesia, em que se afeta naturalidade, segundo o preceito cortesão da sprezzatura. Não por acaso, seus poemas são escritos no estilo médio do gênero lírico-pastoral.

${ }^{39}$ SIDNEY. Op. cit., p. 236: "figuring forth good things"; "which doth, contrariewise, infect the fancy with unworthy objects".

${ }^{40}$ Cf. QUINTILIANO, Institutio Oratoria. Tradução de H. E. Butler. Cambridge, MA: The Loeb Classical Library, Harvard University, 1986, Book X, I. 81: "we shall all admit that Plato is supreme whether in acuteness or perception or in virtue of his divine gift of style, which is worthy of Homer. For he soars high above the levels of ordinary prose [...] and seems to me to be inspired not by mere genius, but, as it were, by the oracles of the god of Delphi”.

${ }^{41}$ SIDNEY. Op. cit., p. 238: "And truly even Plato, whosoever well considereth shall find that in the body of his work, though the inside and strength were philosophy, the skin as it were and beauty depended most of poetry". Em seguida, Sidney lembra a descrição de circunstâncias, a ordenação do banquete, as caminhadas prazerosas, entre outros exemplos, como presença de elaboração poética em Platão. Cf., sobre linguagem poética na filosofia, QUINTILIANO. Op. cit., V, XI. 39-40: "As for reflexions drawn from the poets, not only speeches, but even the works of the philosophers, are full of them; for although the philosophers think everything inferior to their own precepts and 
writings, they have not thought it beneath their dignity to quote numbers of lines from the poets to lend authority to statements."

42 SIDNEY. Op. cit., p. 241: "that poesy, thus embraced in all other places, should only find in our time a hard welcome in England, I think the very earth lamenteth it, and therefore decketh our soil with fewer laurels than it was accustomed".

${ }^{43}$ LONGINUS. On the Sublime. Tradução de W.H. Fyfe. Cambridge; London: Harvard University p. 211. Loeb Classical Library: "Zealous imitation of the great prose writers and poets of the past. That is the aim, dear friend; let us hold to it with all our might"; "Emulation will bring those great characters before our eyes".

${ }^{44}$ Ibidem, p. 215.

${ }^{45}$ CINTHIO. Op. cit., p. 48: "[the poet] ought to follow the path of others not as a slave but as those who, retaining their power, will not depart from what is essential to write artistically, as is the custom of good poets".

${ }^{46}$ ASCHAM. Op. cit., p. 135: "Imitation is a facultie to expresse livelie and perfitelie that example which ye go about to folow. And of it self it is large and wide: for all the workes of nature, in a manner be examples for arte to folow". Cf. o dicionário de Thomas Thomas, Dictionarium Linguae Latinae et Anglicanae. London, 1587: "Aemulatio, onis. Emulation: following: imitation with desire to excell". Os interessados em consultar verbetes de dicionários ingleses dos séculos XVI e XVII podem acessar o site da LEME (Lexicons of Early Modern English) no endereço http://leme.library.utoronto.ca/.

${ }^{47}$ ASCHAM. Op. cit., p. 139: "The second kind of Imitation is to folow for learning of tonges and sciences the best authors. Here riseth emonges proude and envious wittes a great controversie, whether one or many are to be folowed: and if one, who is that one: Seneca or Cicero: Salust or Caesar, and so forth in Greek and Latin".

${ }^{48}$ Ibidem, p. 136: "[...] if ye would speake as the best and wisest do, ye must be conversant, where the best and wisest are: but if yow be borne or brought up in a rude contrie, ye shall not chose but speake rudelie: the rudest man of all knoweth this to be trewe. Yet neverthelesse the rudenes of common and mother tonges is no bar for wise speaking. For in the rudest contrie and most barbarous mother language many be found can speake very wiselie: but in the Greeke and Latin tonge, the two onelie learned tonges, which be kept not in common taulke but in private bookes, we finde alwayes wisdome and eloquence, good matter and good utterance, never or seldom asonder".

${ }^{49}$ SIDNEY. Op. cit., p. 242: "Chaucer, undoubtedly, did excellently in his 'Troilus and Criseyde' [...]. Yet he had great wants, fit to be forgiven in so reverent an antiquity".

50 Ibidem, p. 227: "which God knoweth wanteth much of a perfect poesy".

${ }^{51}$ CINTHIO. Op. cit., p. 113: "I prefer in this connection not to discuss Dante, since through either the fault of his time or his own nature he took such liberties that his license became vice"

${ }^{52}$ SIDNEY. Op. cit., p. 249: "[...] to believe, with Aristotle, that [poets] were the ancient treasurers of the Grecians' divinity; to believe, with Bembus, that they were first bringers-in of all civility; to believe, with Scaliger, that no philosopher's precepts can sooner make you an honest man than the reading of Virgil; to believe, with Clauserus, the translator of Cornutus, that it pleased the heavenly deity, by Hesiod and Homer, under the veil of fables, to give us all knowledge, logic, rhetoric, philosophy natural and moral, and quid non?; to believe, with me, that there are many mysteries contained in poetry, which of purpose were written darkly, lest by profane wits it should be abused; to believe, with Landino, that they are so beloved of the gods that whatsoever they write proceeds of a divine fury". 
${ }^{53}$ ASCHAM. Op. cit., p. 139. Cf. QUINTILIANO, X, II, 4: "The first point, then, that we must realise is that imitation alone is not sufficient, if only for the reason that a sluggish nature is only too ready to rest content with the invention of others." Este é o entendimento predominante de preceptistas do continente; cf. TESAURO, E. "Argúcias Humanas". Tradução de Gabriela Cipollini e João Adolfo Hansen. In: Revista do IFAC. Ouro Preto, IFAC-UFOP, dez. 1997, n 4, p. 7: "é verdade que imitar não é usurpar as metáforas e as agudezas, tais quais as ouves ou lês: porque por isso não obterias elogios de imitador, mas reprovações de ladrão".

${ }^{54}$ Citado em GRIGERA, L. L. "The Classical Tradition in Spain". In: A Companion to the Classical Tradition. Ed. Craig W. Kallendorf. Blackwell Publishing, p. 200.

${ }^{55}$ Cf. DU BELLAY, J. La Deffence, et illvstration de la Langue Francoyse. Paris, 1549: "\& ne me puys assez emerueiller de l'etrange opinion d'aucuns scauans, qui pensent que nostre vulgaire soit incapable de toutes bonnes lettres, \& erudition: comme si vne inuention pour le Languaige seulement deuoit estre iugée bonne, ou mauuaise". Fac-símile disponível no site da Biblioteca Nacional Francesa, em http://gallica.bnf.fr/ark:/12148/bpt6k1050733.

56 TUVE, R. Elizabethan and Metaphysical Imagery: Renaissance Poetic and Twentieth-Century Critics. Chicago: University of Chicago, 1965, p. 36.

${ }^{57}$ PUTTENHAM. Op. cit., I, 1: "A Poet is as much to say as a maker. And our English name well conformes with the Greek word: for of poiyin to make, they call a maker Poeta".

58 SIDNEY. Op. cit., p. 241.

${ }^{59}$ WILSON, T. An English Rhetoric...

${ }^{60}$ Dictionaire Francois Latin. Diversos dicionários franceses do século XVI estão disponíveis em fac-símiles no site da Biblioteca Nacional Francesa, em http://gallica.bnf.fr/.

${ }^{61}$ BUXTON, J. Sir Philip Sidney and the English Renaissance. London: Macmillan, 1966, p. 5. Cf. HANSEN, J. A. A sátira e o engenho: Gregório de Matos e a Bahia do século XVII. Op. cit., p. 32: "Ao poeta seiscentista nada é mais estranho que a originalidade expressiva, sendo a sua invenção antes uma arte combinatória de elementos coletivizados repostos numa forma aguda e nova que, propriamente, expressão de psicologia individual 'original', representação realista-naturalista do 'contexto', ruptura estética com a tradição etc.".

${ }^{62}$ Citado em The Complete Poetry and Selected Prose of John Donne. New York: Modern Library, 1994.

${ }^{63}$ Introdução a O pensamento vivo de Montaigne. Tradução de Sérgio Milliet. São Paulo: Edusp, 1975, p. 12.

64 Ibidem, p. 27.

${ }^{65}$ An Anatomie of the World, The First Anniversary. Wherein, by occasion of the untimely death of mistress Elizabeth Drury, the frailty and the decay of this whole world is represented, 1611. In: Poems, by J.D. London: 1633, 1 ed., p. 247. A primeira edição dos poemas de Donne está disponível em fac-símile no site Digital Donne, em http://digitaldonne.tamu.edu.

66 Ibidem, p. 247-248. O poeta emula esses últimos dísticos ao longo do poema, efetuando variações nos argumentos: "She, shee is dead, she's dead; when thou know'st this, / Thou knowest how ugly a monster this world is"; "She, shee is dead; shee's dead: when thou knowest this / Thou knowest how lame a criple this world is".

${ }^{67}$ Citado em VICKERS, B. (org.) English Renaissance Literary Criticism. Oxford: Oxford University, 2000, p. 530: "That Donne's Anniversary was profane and full of blasphemies. That he told Mr. Donne, if it had been written of the Virgin Mary it had been something; to which he answered, that he described the idea of a woman, and not as she was". 
${ }^{68}$ Cf. ARISTÓTELES. Op. cit., p. 345: "Se, além disso, se critica a ausência de verdade, é possível responder que o autor representou as coisas como elas devem ser, a exemplo de Sófocles, que dizia ter pintado os homens tais quais deviam ser".

${ }^{69}$ In: The Complete Poetry and Selected Prose of John Donne. Op. cit., p. 382: "my defence is, that my purpose was to say as well as I could: for since I never saw the Gentlewoman, I cannot be understood to have bound myself to have spoken just truths, but I would not be thought to have gone about to praise her, or any other in rime: except I took such a person, as might be capable of all that I could say". Cf. John Donne: The Complete English Poems. Ed. by A. J. Smith. London: Penguin Books, 1996, p. 594: "it became me to say not what I was sure was just truth, but the best I could conceive; for that had been a new weakness in me, to have praised anybody in printed verses, that had not been capable of the best praise that I could give".

${ }^{70}$ In: BUXTON, J. Sir Philip Sidney and the English Renaissance. London: Macmillan, 1966, p. 26.

${ }^{71}$ Ibidem.

${ }^{72}$ ARISTÓTELES. Op. cit., p. 344.

${ }^{73}$ Cf. SIDNEY. Op. cit., p. 218: "as the constant though lamenting look of Lucretia, when she punished in herself another's fault; wherein he painteth not Lucretia whom he never saw, but painteth the outward beauty of such a virtue".

${ }^{74}$ CINTHIO. Op. cit., pp. 161-163.

${ }^{75}$ Cf. a referência a Zêuxis, pintor grego, em DIONÍSIO DE HALICARNASSO. Tratado da imitação. Tradução de Raul Miguel Rosado Fernandes. Lisboa: Centro de Estudos Clássicos das Universidades de Lisboa, 1986, p. 52: "quando ele estava a pintar um nu de Helena, mandaram-no ver, nuas, as raparigas da cidade, não porque fossem todas belas mas porque não era natural que fossem todas feias sob todos os aspectos. O que em cada uma havia digno de ser pintado reuniuo ele na figuração de um só corpo [do nu de Helena]" Cf. também CíCERO. De inventione, II, 1, em que expande o mesmo tópico retórico sobre a imitação. 